\title{
Human Derived Cardiomyocytes: A Decade of Knowledge After the Discovery of Induced Pluripotent Stem Cells
}

\author{
Andrea Barbuti, ${ }^{1}$ Patrizia Benzoni, ${ }^{1}$ Giulia Campostrini, ${ }^{1}$ and Patrizia Dell'Era ${ }^{2 *}$ \\ ${ }^{1}$ Department of Biosciences, Università degli Studi di Milano, Milan, Italy \\ ${ }^{2}$ Cellular Fate Reprogramming Unit, Department of Molecular and Translational Medicine, Università degli Studi di Brescia, Brescia, Italy
}

Ten years ago Yamanaka's lab identified a way to reprogram terminally differentiated cells to a pluripotent state, similar to that of embryonic stem cell. This procedure opened the road for the generation of postmitotic human cells, that have completely lost the replication potential. The initial excitement waned when it was observed that the cells produced by this method are somehow immature and do not resemble the adult phenotype. In the absence of cellular markers that recognize the various maturation steps of induced pluripotent stem cell-derived human cardiomyocytes, we propose to follow their maturation looking at their electrophysiological profile. For this reason, we are first reviewing the most common methods of differentiation, from the preliminary complex procedures to the newly-identified two-step protocols and, second, we report the electrical characteristics of the cells, through electrophysiological analysis of ionic currents that give rise to the action potential. We are aware that each protocol leads to the generation of different cardiomyocyte precursors, thus suggesting the need for a wider standardization. The identification of the electrophysiological characteristics of the cells could help in identifying the type and the maturation stage of the obtained cardiomyocyte, thus compensating for the lack of specific markers. Developmental Dynamics 245:1145-1158, 2016. $\odot 2016$ Wiley Periodicals, Inc.

Key words: human cardiomyocytes; electrophysiology; ion channels

Submitted 15 April 2016; First Decision 5 May 2016; Accepted 5 May 2016; Published online 6 September 2016

\section{Introduction}

Cardiovascular events are the leading cause of deaths worldwide and researchers have unraveled many molecular alterations at the bases of these life-threatening events, mainly thanks to the use of animal models recapitulating the phenotypic manifestations of human diseases. This has led to the development of new drugs and therapies alleviating this problem, which remains the major concern of modern society (Mozaffarian et al., 2015). However, although many efforts have been placed during these years to build heterologous expression systems or animal models of cardiovascular diseases, they do not always comprehensively recapitulate human alterations at the cellular levels and response to drugs. Action potential waveform and the underlying currents, typical of human cardiomyocytes (CMs), often differ quite significantly from those of either murine CMs or cells of larger mammals (Milani-Nejad and Janssen, 2014).

For example, in mice, the resting heart rate is 10 -fold higher than in humans, while the time between depolarization and repolarization of ventricles (QT interval) is one fourth of the typical human counterpart (Kaese and Verheule, 2012). Consequently,

Grant sponsor: Fondazione Cariplo; Grant numberss: 2014-1090, 2014-0822.

*Correspondence to: Patrizia Dell'Era, Cellular Fate Reprogramming Unit, Department of Molecular and Translational Medicine, University of Brescia, Viale Europa, 11, 25123 Brescia, Italy. E-mail: patrizia.dellera@ unibs.it many important questions concerning mechanisms underlying cardiac disorders remains unanswered. Some studies have been also carried out directly on human cardiac samples but, beyond being a scarce source of cells, they often come from severely compromised hearts that have undergone important remodeling processes, making it difficult to discern between the cause and the effect of the pathology.

In 2006, Yamanaka's group demonstrated the possibility to reprogram the fate of both murine and human somatic cells bringing them back to a pluripotent state (Takahashi and Yamanaka, 2006; Takahashi et al., 2007), and a decade after his discovery, induced pluripotent stem cells (iPSC) are emerging as the most suitable cellular model to study human diseases. The strength of this technology resides in the possibility to start the process using cells withdrawn from patients carrying a specific genetic background, including those alterations responsible for the pathology. The availability of these patient- and pathologyspecific iPSC provides an unlimited source of any desired specialized cell that will contribute to model in vitro the molecular causes of the pathology. Using human iPSC-derived CMs (iPSC$\mathrm{CMs}$ ) researchers can model cardiac genetic diseases in a culture dish thus enabling the characterization of the biological mechanisms underlying the human pathology, as well as generating a powerful model for personalized drug screening.

Article is online at: http://onlinelibrary.wiley.com/doi/10.1002/dvdy. 24455/abstract

(C) 2016 Wiley Periodicals, Inc. 
Here, we will briefly illustrate the procedures to obtain human CMs from iPSC while we will discuss in detail the electrophysiological characteristics of iPSC-CMs that can help in distinguishing and identifying CM subpopulation.

\section{Cardiomyocyte Differentiation From iPSC}

During gastrulation, CMs emerge from the mesodermal layer, in particular from the anterior region of the primitive streak. The balance between inductive signals, mainly FGF and BMP, and repressive signals, mostly Wnt and beta-catenin, induce the development of cardiac progenitors (Brade et al., 2013). After their migration to the cardiac crescent, the primitive beating heart tube is formed, composed by synchronously beating small myocytes (Brade et al., 2013). The contractile impulse begins within the primary pacemaker area in the primitive atrium that will later evolve in the sino atrial node, where the fast beating pacemaker myocytes will reside. As development proceeds, CMs in different anatomical regions of the hearts, comprising atria and ventricles, will be generated and linked by the conduction system that includes the sinus node, the internodal pathways, the atrioventricular (AV) node, the AV bundles, and Purkinje fibers. Each $\mathrm{CM}$ subtype has its own electrical properties such as the form of the action potential (AP), the contraction rate, and the presence of specific currents that can be measured electrophysiologically.

Within these years, several efforts have been made to develop a protocol able to give rise to a large number of hiPSC-derived CMs. Some of the attempts toward this goal included: (a) the use of defined culture media that, avoiding animal components, will facilitate the therapeutic use of pluripotent stem cells; (b) specific matrices made of recombinant proteins such as vitronectin or laminin; (c) aggregation plates to standardize the production of embryoid bodies (EBs); (d) the development of commercially available $\mathrm{CM}$ differentiation media.

Early protocols for generating CMs involved the formation of three dimensional structures called embryoid bodies (EB), a procedure that works very well for mouse pluripotent stem cells where, in the presence of serum, the formation of EBs resemble the process of embryogenesis generating cells belonging to the three germ layers (Desbaillets et al., 2000). Nevertheless, using this system, the cardiac differentiation efficiency of human embryonic stem cells (ESC), the physiological counterpart of iPSC, is limited to 5-10\% (Kehat et al., 2001). Shortly thereafter, several protocols included iPSC stimulation with bioactive molecules and in 2007 a mesodermal induction of EBs based on the combination of activin A with FGF2, raised the differentiation efficacy up to 25\% (Burridge et al., 2007). At variance, a treatment based on the stimulus that endodermal cells exert on cardiac crescent during development was achieved (Mummery et al., 2003); This suggests that a direct co-culture of iPSC with mouse endoderm-like cells END2 is effective, but its use is limited therapeutically by the presence of animal cells (Mummery et al., 2003).

Over time, the proposed protocols become more complex and the addition of newly discovered mesoderm inducting factors (e.g., BMP4 or WNT3A) slightly increased the percentage of CMs (Yang et al., 2008; Tran et al., 2009). Nevertheless, the discovery that by using the GSK3B inhibitor, CHIR99021, mesoderm specification can be raised up to 90\% (Gonzalez et al., 2011), together with the finding that cardiac specification can be obtained by inhibiting Wnt signaling, using either DKK1 (Yang et al., 2008) or the small molecules IWRs (Ren et al., 2011), led to a great improvement of PSC-derived CM differentiation. Indeed, starting from an undifferentiated PSC monolayer, a simple and chemically defined three-step protocol raises CM population up to 8090\% (Burridge et al., 2014). In addition, in the human system the use of anti VCAM1 antibody in the early differentiation steps allowed the sorting of the CM population, comprising ventricular as well as pacemaker cells (Uosaki et al., 2011), whereas in the murine counterpart CD166 represent a specific marker for selecting pacemaker CMs (Scavone et al., 2013).

\section{Maturity State of iPSC-Derived Cardiomyocytes}

In the healthy adult mammalian myocardium, the majority of CMs are unable to divide. The transition of CMs from a proliferative state, characteristic of embryonic stages, to the differentiated, phenotype typical of adult cells is a highly regulated process. The switch in the growth potential of CMs occurs in the mouse at or shortly after birth, in the rat between 3 and 4 days post-natally, whereas in humans, CMs stop to divide after 7 months of age (Li et al., 1996; Poolman and Brooks, 1998; Huttenbach et al., 2001).

The first description of CMs derived from hiPSC dates back to 2009. Using an EB-based protocol, beating cells that expressed several cardiac genes such as Nkx2,5, myofilament proteins, atrial natriuretic factor, and phospholamban were generated and maintained in culture for at least 60 days (Zhang et al., 2009). At variance with adult CMs, iPSC-CMs generally show immature characteristics in morphology, cytoskeletal proteins, and ion channel expression and organization (Yang et al., 2014b; van den Berg et al., 2015). The immaturity of early stage hiPSC-CMs is also reflected by the inability to develop a well-organized excitation-contraction coupling machinery. Indeed, iPSC-CMs lack clear T-tubuli, show disorganized sarcomeric striations, and an immature $\mathrm{Ca}^{2+}$ handling attributed to the differential developmental expression profiles of specific proteins such as calsequestrin or phospholamban and insensitiveness to drugs that interfere with sarcoplasmic $\mathrm{Ca}^{2+}$ release or reuptake (Dolnikov et al., 2006; Lieu et al., 2009; Li et al., 2013).

Ultrastructural studies demonstrated that sarcomeres of hiPSCCMs continue to mature throughout a 1-year culture (Kamamura et al., 2013). Early-stage hiPSC-CMs contained few unaligned myofibrils and immature high-density Z-bands. Within 6 months the myofibrils became more tightly packed and formed parallel arrays accompanied by the appearance of mature $\mathrm{Z}-, \mathrm{A}-, \mathrm{H}-$, and I-bands. M-bands were finally detected in 360-day-old CMs, but expression levels of M-band-specific genes remained low in comparison with those in the adult heart (Ivashchenko et al., 2013). Differences in gene expression paralleled these changes: latestage CMs display increased levels of the sarcomeric proteins MYH6 and MYH7, connexin 43, hyperpolarization activated cyclic nucleotide-gated potassium channel 4 (HCN4), and sarco(endo)plasmic reticulum $\mathrm{Ca}^{2+}$ ATPase (Lundy et al., 2013; Ivashchenko et al., 2013; Kamakura et al., 2013).

Human iPSC-CMs also exhibit immature mitochondria that, during progressive cardiac differentiation, are involved in the metabolic switch where amino acid and anaerobic glycolysis, most prominent in undifferentiated ESC, rapidly decreases, in favor of fatty acid-dependent mitochondrial respiration (Gaspar et al., 2014). The metabolic signature is unique in PSC-CM and indeed a glucose-depleted but lactate-enriched culture medium 
can be used to obtain a purified population of CM (Tohyama et al., 2013).

CMs derived from hiPSC undergo progressive functional changes over time; unlike primary isolated CMs that tend to either undergo apoptosis or dedifferentiate in long-term culture, hiPSC-CMs develop and maintain an efficient phenotype, in terms of ion channel functionality (ion currents), intracellular calcium cycling (calcium transients), responsiveness to cardioactive pharmacological stimuli, and metabolic parameters (Ivashchenko et al., 2013).

To use PSC-CMs for either disease modeling or regenerative purposes, a certain degree of maturation should be acquired; indeed, more mature human CMs, with enhanced contractile performance and with properties closer to that of adult myocardium, may be more useful in resembling the pathological features of elderly patients.

Several approaches have been pursued to improve and to accelerate the maturation of these cells. Recently, mechanical loading of CMs embedded in elastic matrices, the use of substrates with controllable anisotropic topographies, and the application of electrical field stimulation have been exploited (reviewed in Mathur et al., 2016). Moreover, using a specific platform that combines three-dimensional cell cultivation with electrical stimulation, it has been shown that PSC-derived CM acquire a physiological cell hypertrophy, mature their contractile apparatus, improve $\mathrm{Ca}^{2+}$ handling properties and advance their electrophysiological assets (Nunes et al., 2013).

As reported from several studies and commonly for mouse and human ESC-derived CM, hiPSC-CM population is composed by cells that possess different waveforms of action potential, leading to their classification as ventricular-, atrial-, and nodal-like CMs (Ma et al., 2011). At later differentiation times and regardless to the differentiation protocol, ventricular-like cells represent the predominant class of $\mathrm{CMs}$, although different procedures lead to different ratios among CM subtypes (reviewed in Dell'Era et al., 2015). Then, because hiPSC-CM show different electrical properties due to sub-lineage commitment, and different maturation stages related to culture time it becomes mandatory to specify which iPSC-CMs subtype has been used and the time of differentiation/maturation.

\section{Electrophysiological Profile of iPSC-Derived Cardiomyocytes}

Cardiac function depends on the appropriate timing of contraction in various regions, as well as on appropriate heart rate. To keep these functions, electrical activity in each region is adapted to its specialized function. Following differentiation, iPSC-CMs obtained from various differentiation protocols consist of a mixture of electrophysiological phenotypes. Classification of hiPSCCMs as nodal-, atrial-, and ventricular-like is based on the resemblance of their action potential (AP) to each of the three principal phenotypes found in the adult heart (Schram et al., 2002).

A summary of the main electrophysiological characteristics of human iPCS-CMs is reported in Table 1.

Young cardiac cells show spontaneous contraction whose frequency has been extensively evaluated. Indeed, reported beating rates ranged from 28 up to 118 beats per min (bpm), thus showing a very high variation. Extended values are also shown for the diastolic potentials, ranging from $-55 \mathrm{mV}$ to $-75 \mathrm{mV}$, regardless of differentiation method.

Several papers described the three subtypes of CMs, classified according to AP waveform, maximum diastolic potential (MDP), upstroke velocity and action potential duration (APD); nevertheless, it should be pointed out that none of these parameters is comparable to that of an adult cardiomyocyte (Yang et al., 2014a).

As shown in Table 1 cells with ventricular-like action potentials were those most frequently encountered (from 48 to 76\%) and typically displayed a more negative MDP $(<-60 \mathrm{mV})$, a rapid action potential upstroke (from 9 to $50 \mathrm{~V} / \mathrm{s}$ ) and a distinct plateau phase between the $50 \%$ and $90 \%$ of repolarization, that brings the ratio of ADP90/APD50 lower than 1.5. Atrial-like cells were characterized by the absence of a distinct plateau during repolarization (APD90/APD50 higher than 1.5) and typically exhibited spontaneous activity that was higher in frequency than that observed in ventricular-like cells.

Finally, nodal-like cells were distinguished by less negative MDP ( > -60 mV), smaller amplitude AP, a slower AP upstroke, and a pronounced phase 4 depolarization preceding the AP upstroke. In Figure 1 (reported from Doss et al., 2012) several examples of AP waveforms are reported, and they are arranged by the number of days post differentiation (from 19 to 119 days). Although 15\% (4/27) were classified as atrial-like APs (denoted with an A) and 85\% (23/27) as ventricular-like (unmarked APs) the figure reveals a nearly continuous range of AP morphologies, highlighting the subjective nature of distinctions made on the basis of AP profiles. Of note, none of the reported APs satisfied the criteria for nodal-like (i.e., $\mathrm{APD}_{90} / \mathrm{APD}_{50}$ ratios $(\mathrm{RO})>1.5+$ low amplitude + less negative MDP + low Vmax).

As stated before the AP-based classification refers to the different types of adult heart cells not taking into account the fact that the progression of in vitro cardiac maturation leads to the formation of intermediate stages hardly classifiable using the above criteria. Indeed, just the addition of T3 hormone to the maintenance medium changes hiPSC-CM AP characteristics (Ribeiro et al., 2015). Because it was demonstrated that APD90, MDP, dV/dt max are related to the number of days post differentiation (Doss et al., 2012), we would consider electrophysiological changes as a sign of hiPSC-CM maturity.

Because the shape of the AP is the result of various inwardly and outwardly ion currents present in the CMs (reported in Fig. 2), in the following paragraphs we review the presence, the characteristic of hiPSC-CM currents, highlighting the description of their modifications during maturation.

\section{Hyperpolarization-Activated Cation Currents $\left(I_{f}\right)$}

The funny current $\left(I_{\mathrm{f}}\right)$ is an inward mixed $\mathrm{Na}^{+} / \mathrm{K}^{+}$current that activates upon membrane hyperpolarization. It activates during the diastolic depolarization (DDL) phase of the action potential of autorhythmic cells, thus playing a fundamental role in the initiation of the spontaneous activity and in the control of the firing rate (Baruscotti et al., 2010). The $I_{\mathrm{f}}$ current is, therefore, also known as pacemaker current. It is mediated by the family of HCN channels. The four members of the family (HCN1-4) are differentially expressed in the human heart, with HCN4 being the most abundant in the sinoatrial node, followed by HCN1, while HCN2 


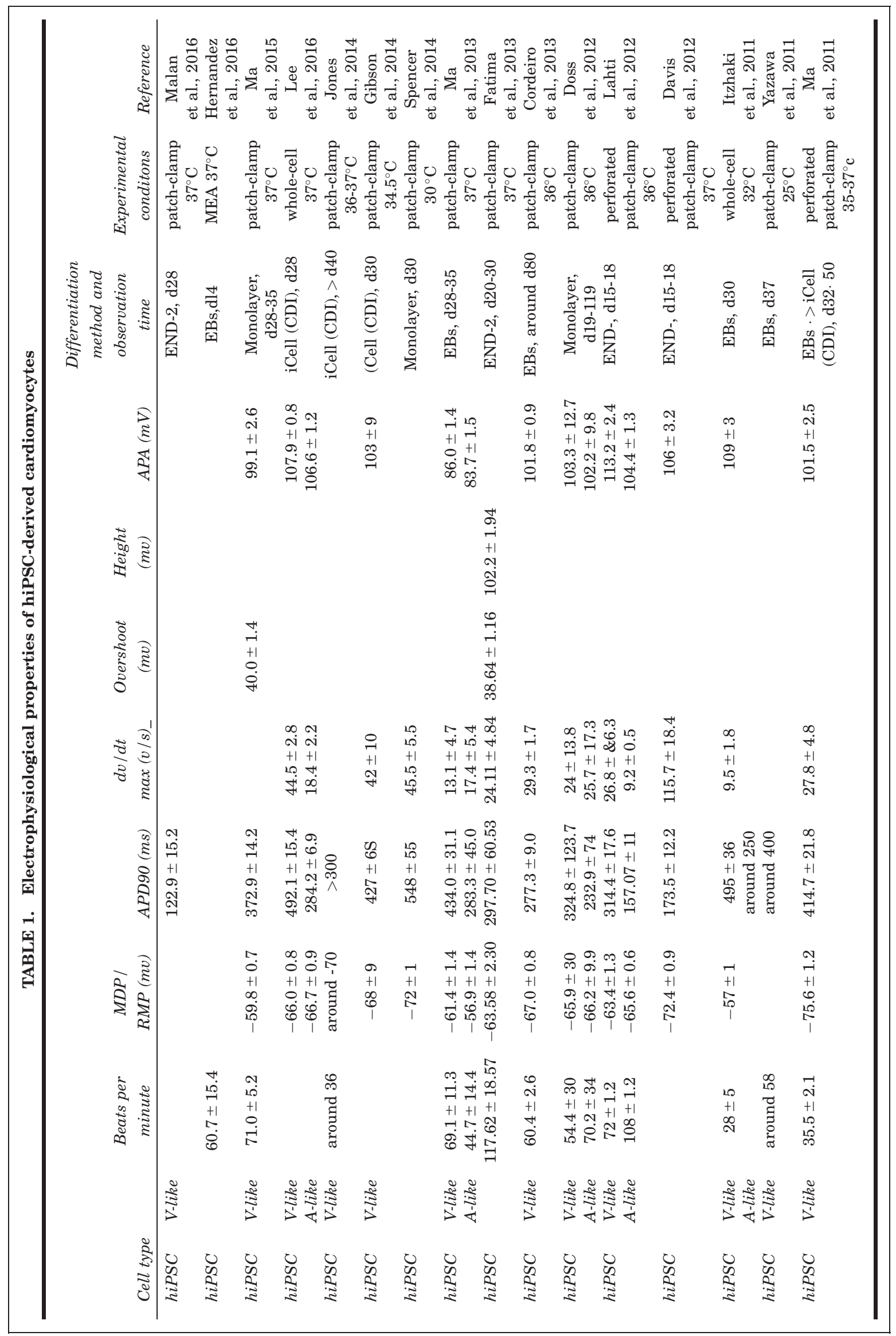



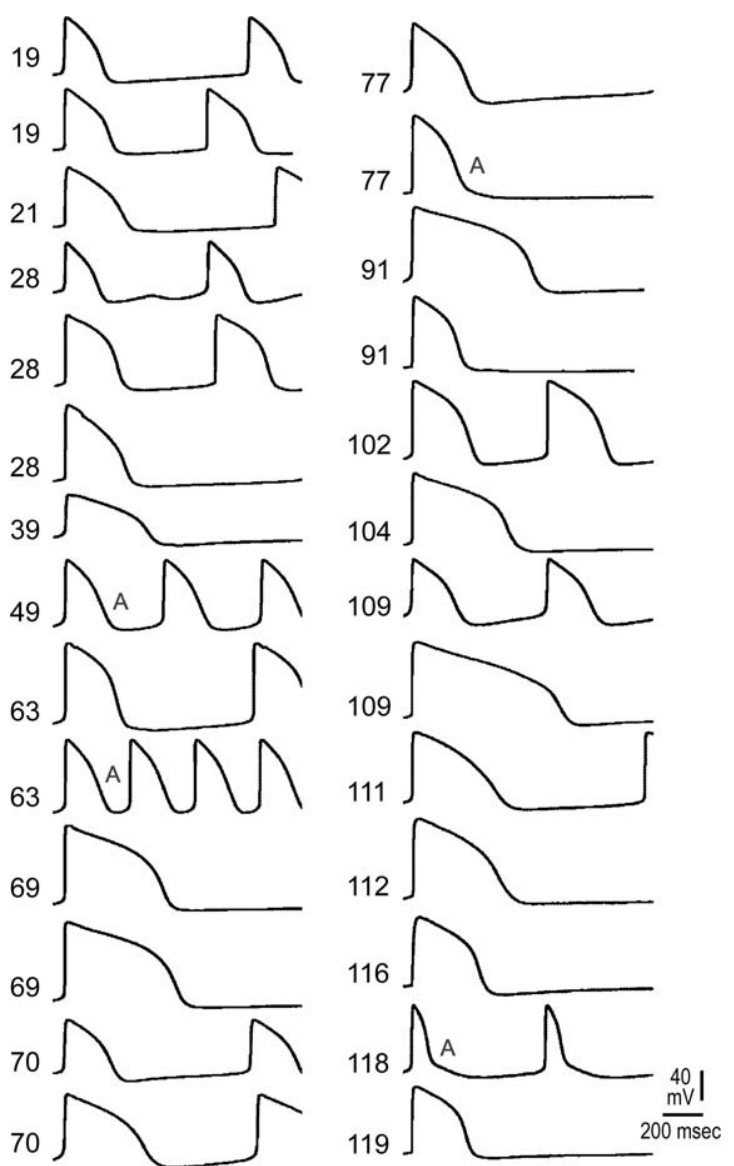

Fig. 1. Action potential morphologies from iPSC-derived cardiomyocytes. Illustration credit to Doss et al., 2012. is the most expressed in the working myocardium (Baruscotti et al., 2010). HCN4 specifically marks the first heart field at the earliest stages of mouse cardiogenesis, as well as cardiomiogenic progenitors derived from hESCs (Liang et al., 2013; Später et al., 2013). The expression of HCN channels was studied during hiPSC cardiac differentiation.

Two independent studies showed that HCN2 levels increase with time in culture until day 21 (Zwi et al., 2009; Mehta et al., 2011). Instead there are some controversies on HCN4 levels, which have been reported to decrease (van den Heuvel et al., 2014) or increase (Lundy et al., 2013) over time. A variation in HCN channel mRNA levels was observed also during hESC differentiation and also in this case different groups reported controversial data. HCN1 was found to increase by almost 50\% from 3 weeks to 7 weeks of culture (Synnergren et al., 2012), however, a decrease in the levels of HCN1 and HCN4 was observed between days 15 and 30 and days 55 and 110 (Sartiani et al., 2007).

$I_{\mathrm{f}}$ current was recorded by very few studies in hiPSC-CMs (Table 2). Ma and colleagues (2011) recorded $I_{\mathrm{f}}$ from hiPSC-CMs (iCell Cardiomyocytes; CDI, Madison, WI) and found a current density of $-4 \mathrm{pA} / \mathrm{pF}$ at $-120 \mathrm{mV}$. Lee and colleagues (2016) recorded $I_{\mathrm{f}}$ current from hiPSC-CMs after 28 days of differentiation as the zetabradine-sensitive current. The current density they found was lower (around $-1 \mathrm{pA} / \mathrm{pF}$ ), but similar to the one that was found in adult human ventricular cardiomyocytes (Lee et al., 2016). This is in agreement with the higher percentage of ventricular-like CMs they obtained compared with atrial- and sinoatrial-like ones, on the basis of the AP shape. However, because zetabradine appears to block around 50\% of the timedependent hyperpolarization-activated current, the $I_{\mathrm{f}}$ current density, determined from the sensitive current, may be underestimated. We have recently recorded an $I_{\mathrm{f}}$ current in hiPSC-CMs
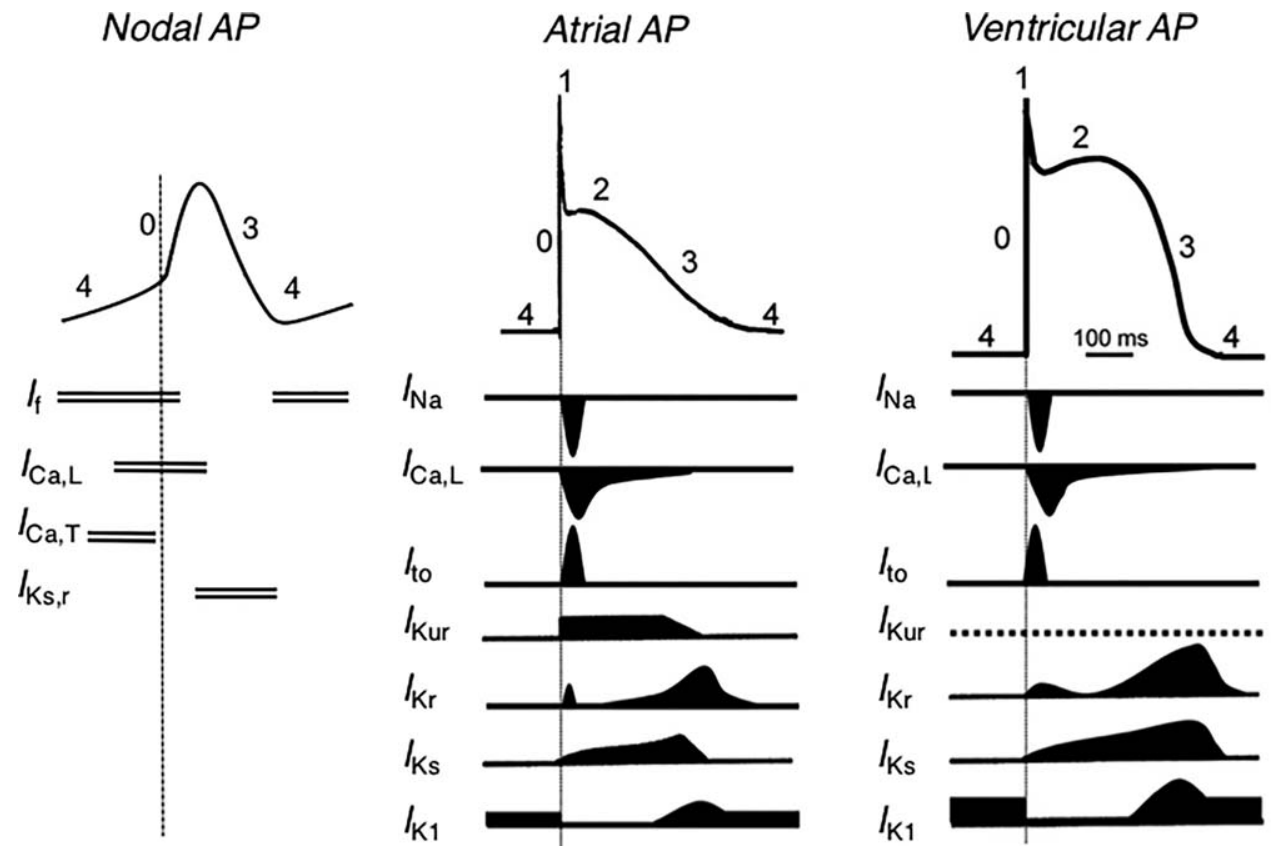

Fig. 2. Typical action potential waveforms of nodal, atrial, and from working ventricular $\mathrm{CM}$, showing the various phases (0-4) and the time course of the principal ionic currents. 


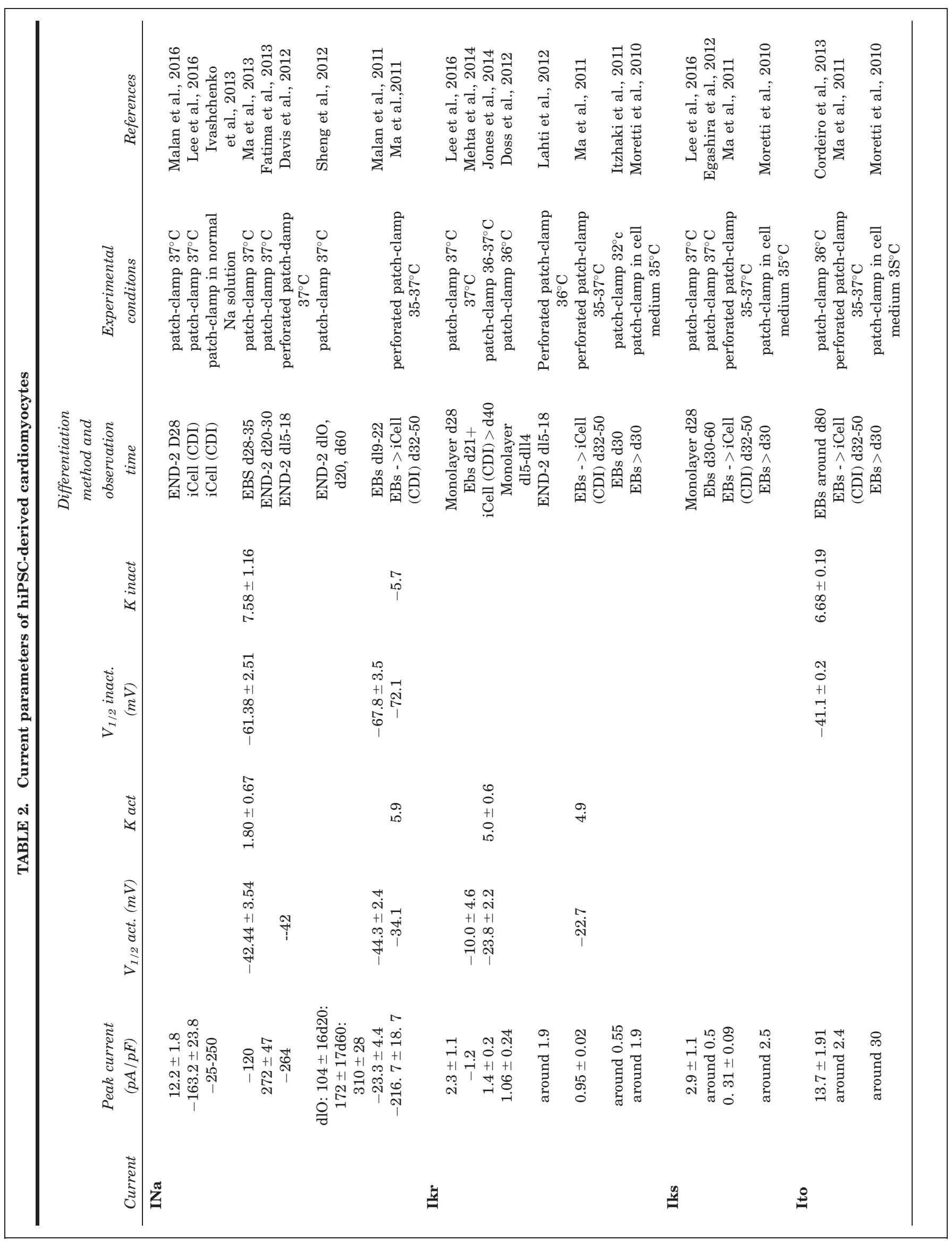




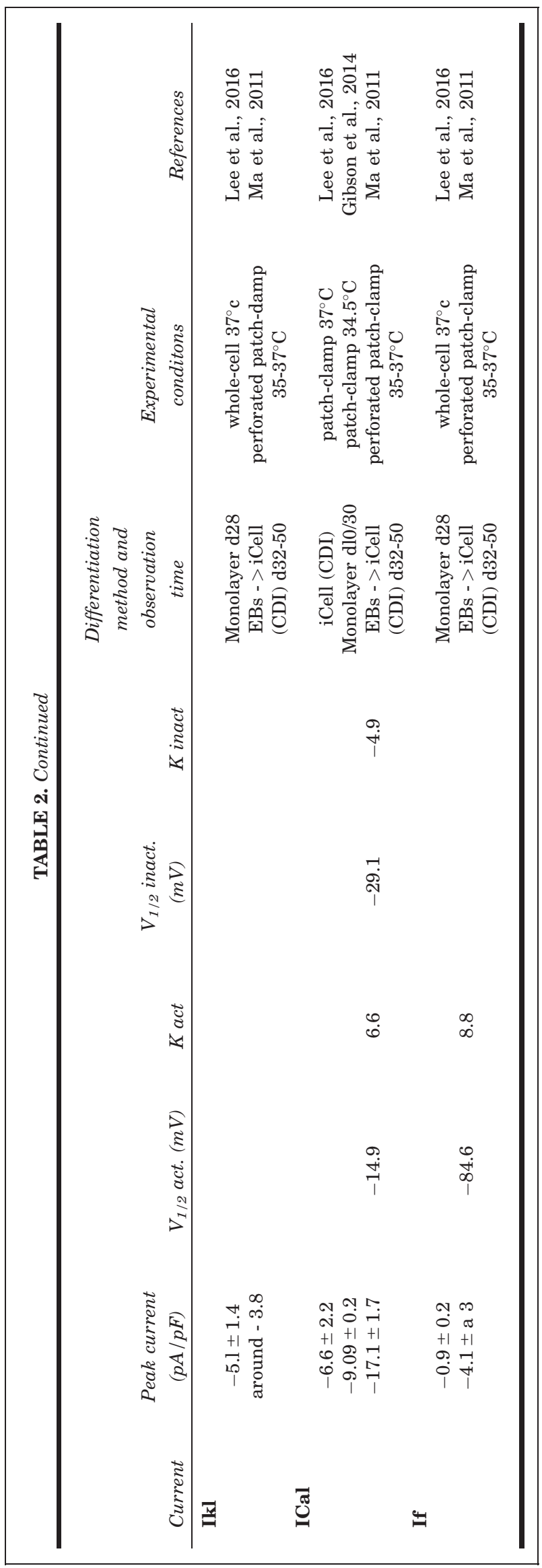

with a density at $-125 \mathrm{mV}$ comparable to that found by Ma and colleagues (2011; around $-4 \mathrm{pA} / \mathrm{pF}$, data not shown).

The current densities observed in hiPSC-CMs are generally larger than those found in ventricular and atrial adult CMs (Wettwer et al., 1994; Stillitano et al., 2013). This robust $I_{\mathrm{f}}$ current may represent a further indication of the immaturity of these cells and account for the automaticity of hiPSC-CMs obtained with the different differentiation methods. The same kind of autorhythmic phenotype was also observed in hESC-derived CMs, which display an $I_{\mathrm{f}}$ current density comparable with that of hiPSC-CMs (Weisbrod et al., 2013).

While working myocardium currents increase in hiPSC-CMs during maturation in culture, it is not clear whether this is also true for $I_{\mathrm{f}}$ current density. The densities reported were recorded, however, in cells expressing on average large sodium and potassium currents (Ma et al., 2011; Lee et al., 2016), normally hallmark of a certain hiPSC-CM maturation toward atrial- or ventricular-like phenotype. Further studies will need to clarify the trend of $I_{\mathrm{f}}$ current expression in hiPSC-CMs during maturation and notably whether the expression of $I_{\mathrm{f}}$ current becomes restricted to a smaller population of sinoatrial-like cells.

\section{Sodium Current $\left(I_{\mathrm{Na}}\right)$}

The cardiac sodium current $\left(I_{\mathrm{Na}}\right)$ is mediated by voltage-gated channels that are composed by an alfa-subunit forming the pore and some accessory beta-subunits (Catterall, 2012). There are various alfa-subunits expressed in mammals that possess different pharmacological properties and expression patterns. In the human heart, the sodium channel $\mathrm{Na}_{\mathrm{v}} 1.5$ is the most expressed subunit, representing the large majority (around 90\%) of the sodium channels in atrial cells (Sakakibara et al., 1992; Kaufmann et al., 2013). $\mathrm{Na}_{\mathrm{v}} 1.5$ is characterized by a weak sensibility to TTX, because it requires several micromolars of TTX $(30-100 \mu \mathrm{M})$ for inhibition (Sakikabara et al., 1992).

$\mathrm{Na}_{\mathrm{v}} 1.5$ expression is higher in the ventricles compared with the atria (Furukawa et al., 1995) and higher in the working myocardium compared with the conduction system, even if it contributes to the pacemaking (Baruscotti et al., 2000).

The opening of $\mathrm{Na}_{\mathrm{v}}$ channels upon membrane depolarization beyond $-70 \mathrm{mV}$ provides a rapid influx of $\mathrm{Na}^{+}$causing the membrane to further depolarize toward $\mathrm{Na}^{+}$reverse potential (phase 0 of the action potential). The inactivation of $\mathrm{Na}_{\mathrm{v}} 1.5$ channels occurs few milliseconds after the opening, and membrane hyperpolarization close to the resting potential is necessary to recover from inactivation. For this reason, if the MDP is quite depolarized, a fraction of $\mathrm{Na}_{\mathrm{v}} 1.5$ channels will be inactivated and, as a consequence, the slope (dV/dtmax) of phase 0 will be reduced.

The data on hiPSC-CMs, which analyzed the properties of $I_{\mathrm{Na}}$, are summarized in Table 2. Most of the studies used hiPSC-CMs derived from patients and analyzed CMs obtained from hiPSC of healthy individuals as a control. Because it was not the goal of those studies, the electrophysiological characterization of the iPSC-CMs often was not much detailed. Moreover, the external solutions and the holding potential used to record $I_{\mathrm{Na}}$ vary among different studies, thus making any comparison useless.

The first record of $I_{\mathrm{Na}}$ in hiPSC-CMs was from Malan and collaborators in 2011 with a study on longQT3 syndrome. They showed that $66 \%$ of cells displayed $I_{\mathrm{Na}}$ at early stage (day 12), and the fraction increased up to 93\% afterward (day 19-22). Peak current density was $23 \mathrm{pA} / \mathrm{pF}$ (in external solution containing 
$7 \mathrm{mM} \mathrm{NaCl}$ and with a holding potential of $-100 \mathrm{mV}$ ) and mean $\mathrm{V}_{1 / 2}$ of activation and inactivation were -44.3 and -67.8 , respectively. The resting potential of the analyzed cells was around -80 $\mathrm{mV}$, which is consistent with the quite fast $\mathrm{dV} / \mathrm{dt}$ of $64.6 \mathrm{mV} / \mathrm{s}$ recorded (Malan et al., 2011). A recent study from the same group reported comparable $I_{\mathrm{Na}}$ current density (Table 2; Malan et al., 2016).

In other studies, while activation and inactivation properties were similar, much higher $I_{\mathrm{Na}}$ current densities were found. This was mainly due to the concentration of sodium in the extracellular solution (Table 2); however, the $\mathrm{dV} / \mathrm{dt}$ on the action potentials recorded was slower and accordingly these cells had more depolarized MDP (Table 1 and 2: Ma et al., 2011; Fatima et al., 2011; Sheng et al., 2012; Ma et al., 2013; Lee et al., 2016). It must be noticed that these studies, while maintaining a hyperpolarized holding potential $(-100 /-80 \mathrm{mV})$, used external solutions with $\mathrm{Na}^{+}$concentrations ranging between 50 and $145 \mathrm{mM}(50 \mathrm{mM} \mathrm{Ma}$ et al., 2011; 120 mM: Sheng et al., 2012 and Fatima et al., 2011; $130 \mathrm{mM}$ Davis et al., 2012; $135 \mathrm{mM}$ Ma et al., 2013; $140 \mathrm{mM}$ Ivashchenko et al., 2013; 145 mM Lee et al., 2016),

The first data on $I_{\mathrm{Na}}$ expression during maturation in culture were enriched by the study of Sheng and colleagues. They showed that $I_{\mathrm{Na}}$ current density almost doubles in CMs from day 20 to day 60 of differentiation (Table 2, Sheng et al., 2012). However, its contribution to the action potential does not undergo a comparable increase, because the MDP and $d V / d t$ of these cells did not change significantly at the two time points. A subsequent study of Ivanshenko and colleagues monitored $I_{\mathrm{Na}}$ current density in hiPSC-CMs at four time points of differentiation (from day 35 to day 70). Despite using another differentiation protocol (antibiotic-resistent CMs from CDI), also this study showed that $I_{\mathrm{Na}}$ current density gradually increases with time in culture (from ca. 25 pA/pF to ca. 250 pA/pF, Table 2) (Ivashchenko et al., 2013).

An increase of the sodium current during CM maturation is observed also in cardiac differentiation of hESC (Otsuji et al., 2010; Synnergren et al., 2011; Sheng et al., 2012). As in the hiPSC model, the $\mathrm{dV} / \mathrm{dt}$ increases with the hyperpolarization of MDP (Satin et al., 2004), that remains anyway depolarized enough to inactivate a large fraction of sodium channels (Jonsson et al., 2012).

In agreement with these in vitro data, also during heart development an increase in $I_{\mathrm{Na}}$ density is observed, accompanied with hyperpolarization of MDP and increased $\mathrm{dV} / \mathrm{dt}$ (McDonald et al., 1973; Fujii et al., 1988). $I_{\mathrm{Na}}$ current density at early phases of mouse embryonic development (E11-E13) is low (around -10 pA/ $\mathrm{pF}$ ) and some cardiomyocytes (22\%) present only L-type calcium current; by E17-E20 $I_{\mathrm{Na}}$ was found in all the cell tested and the current density was markedly increased (around -120 pA/pF) (Davies et al., 1996; van den Heuvel et al., 2014). Further studies evidenced that $\mathrm{Na}_{\mathrm{v}} 1.5$ expression increases perinatally and postnatally (Harrell et al., 2007; Yu et al., 2011). In humans, the study of $I_{\mathrm{Na}}$ expression during in vivo development are limited. No differences in mRNA levels of $\mathrm{Na}_{\mathrm{v}} 1.5$ were observed between fetal and adult hearts (Synnergren et al., 2012), however, adult atrial cardiomyocytes presented an increased peak current density compared with pediatric cells (Cai et al., 2011).

These studies show that an increase in $I_{\mathrm{Na}}$ current density may represent a general hallmark of maturation. The phase 0 of the action potential of more immature CMs can be sustained indeed mainly by L-type calcium current, presenting a slower $\mathrm{dV} / \mathrm{dt}$, while with maturation $I_{\mathrm{Na}}$ current becomes responsible for this phase causing a steepness of the upstroke. However, $I_{\mathrm{Na}}$ expression can be considered an index only in a relative way, comparing different time points within the same differentiation protocol and recording conditions. A comparison among different studies appears, therefore, yet unfeasible. Notably, despite the increase in $I_{\mathrm{Na}}$ current indicate a certain maturation of the CMs, these cells remain generally depolarized and this reflects in an immature action potential profile even at late days of differentiation, with a relatively slow $\mathrm{dV} / \mathrm{dt}$.

\section{Calcium Currents $\left(I_{\mathrm{Ca}}\right)$}

During the cardiac action potential, $\mathrm{Ca}^{2+}$ enters the cell through depolarization-activated $\mathrm{Ca}^{2+}$ channels as inward $\mathrm{Ca}^{2+}$ current $\left(I_{\mathrm{Ca}}\right)$, which contributes to the action potential plateau (see Fig. 2). $\mathrm{Ca}^{2+}$ entry triggers $\mathrm{Ca}^{2+}$ release from the sarcoplasmic reticulum (SR). The combination of $\mathrm{Ca}^{2+}$ influx and release raises the free intracellular $\mathrm{Ca}^{2+}$ concentration $\left[\mathrm{Ca}^{2+}\right]_{\mathrm{i}}$, allowing $\mathrm{Ca}^{2+}$ to bind to the myofilament protein troponin $\mathrm{C}$, which then switches on the contractile machinery. For relaxation to occur $\left[\mathrm{Ca}^{2+}\right]_{\mathrm{i}}$ must decline, allowing calcium ions to dissociate from troponin (Bers, 2000).

There are two types of voltage-gated calcium currents in the heart classified by their distinct pharmacological and biophysical properties: long lasting calcium current $\left(I_{\mathrm{Ca}, \mathrm{L}}\right)$ and transient calcium current $\left(I_{\mathrm{Ca}, \mathrm{T}}\right)$. The related channels are composed by different $\alpha$-subunits: $\mathrm{Ca}_{\mathrm{v}} 1.2$ and $\mathrm{Ca}_{\mathrm{v}} 1.3$, encoded by CACNA1C and CACNA1D genes respectively, for $I_{\mathrm{Ca}, \mathrm{L}}, \mathrm{Ca}_{\mathrm{v}} 3.1$ and $\mathrm{Ca}_{\mathrm{v}} 3.2$ encoded by CACNA1G and CACNA1H genes, respectively, for $I_{\mathrm{Ca}, \mathrm{T}}$. These channels also require several auxiliary subunits $(\beta, \alpha 2 \delta$, and $\gamma)$ and calmodulin to account for properties found in native currents (for a review see Catterall, 2000).

$I_{\mathrm{Ca}, \mathrm{L}}$ channels open upon depolarization at potentials positive to approximately $-40 \mathrm{mV}$ and inactivate in less than $100 \mathrm{~ms}$. The opening of cardiac L-type $\mathrm{Ca}^{2+}$ channels in response to membrane depolarization is slower than that of $\mathrm{Na}_{\mathrm{v}}$ channels. These channels, therefore, poorly contribute to phase 0 of AP, while $\mathrm{Ca}^{2+}$ entry through these channels underlies the AP plateau (phase 2), especially in ventricular cells (Nerbonne and Kass, 2005).

$I_{\mathrm{CaL}}$ is found in all CMs of the heart and it is critical for triggering $\mathrm{Ca}^{2+}$ release from the SR, a process called $\mathrm{Ca}^{2+}$-induced $\mathrm{Ca}^{2+}$-release (CICR), which is required for initiating the excitation-contraction coupling in working CM (Zhang et al., 2005). Ltype $\mathrm{Ca}^{2+}$ channels are also expressed in sinoatrial node (SAN) and atrioventricular node (AVN) cells, where they play a role in the last part of the diastolic depolarization and in the phase 0 of action potential (Kodama et al., 1997; Mangoni and Nargeot, 2008).

T-type $\mathrm{Ca}^{2+}$ channels are activated at relatively hyperpolarized membrane potentials (approximately $-60 \mathrm{mV}$ ), and inactivate rapidly. $I_{\mathrm{Ca}, \mathrm{T}}$ channels are expressed in the cardiac conduction system (sinoatrial and atrioventricular nodes, HIS Bundle, and Purkinje network) where $I_{\mathrm{Ca}, \mathrm{T}}$ contributes to the diastolic depolarization (Ono and Iijima, 2010). In working myocardium, T-type calcium channels show very low expression levels with a higher expression at embryonic and neonatal stages, while it results almost negligible in adult cardiomyocytes (Ono and Iijima, 2010). So far, despite the attempt made by Ma and colleagues, no T-type $\mathrm{Ca}^{2+}$ current was found in hiPSC-CMs (Ma et al., 2011). 
Electrophysiological studies have demonstrated the presence of a nifedipine-sensitive $I_{\mathrm{Ca}, \mathrm{L}}$ in cultured hiPSC-CMs with a peak current density (at $0 \mathrm{mV}$ ) ranging between $6.6 \mathrm{pA} / \mathrm{pF}$ (Lee et al., 2016) and 9.1 pA/pF (Gibson et al., 2014) at physiological $\mathrm{Ca}^{2+}$ concentration (Table 2), similar to that reported in human ventricular CMs (10.2 pA/pF) (Magyar et al., 2000). The voltage dependence and properties of the $I_{\mathrm{Ca}, \mathrm{L}}$ studied in hiPSC-CMs are similar to those obtained from human ventricular myocytes and hESC-CMs (Pelzmann et al., 1998; Sartiani et al., 2007).

We have seen that $I_{\mathrm{Ca}, \mathrm{L}}$ is robustly expressed in hiPSC-CMs and it sustains the action potential depolarization at early stages of differentiation (15-20 days in culture) when sodium current is mostly not present yet; moreover, $I_{\mathrm{Ca}, \mathrm{L}}$ expression does not change significantly up to day 30-35 of differentiation (our unpublished observation).

Changes in $I_{\mathrm{Ca}, \mathrm{L}}$ during long-term cultured of hiPSC-CMs has not, however, been examined yet, while it is for example known that in hESC-CMs, it increases from $\sim 7.3 \mathrm{pA} / \mathrm{pF}$ after 60 days in culture to $\sim 11 \mathrm{pA} / \mathrm{pF}$ after 240 days in culture (Otsuji et al., 2010).

\section{Transient Outward Potassium Current $\left(I_{\text {to }}\right)$}

The transient outward potassium current $\left(I_{\mathrm{to}}\right)$ is an outward current that occurs during the repolarizing phase 1 of the AP, and it is rapidly activated and inactivated by membrane depolarization. The channels responsible for $I_{\text {to }}$ are formed by $\mathrm{K}_{\mathrm{v}} 4.2$ (encoded by KCND2 gene) and $\mathrm{K}_{\mathrm{v}} 4.3$ (encoded by KCND3 gene) or $\mathrm{K}_{\mathrm{v}} 1.4$ (encoded by KCNA4 gene) alpha subunits (Perrin et al., 2014), complexed with various auxiliary subunits such as KChIP2, DPP6 and DPP10 (Niwa and Nerbonne, 2010). The opening of these voltage-sensitive potassium channels causes a rapid but transient membrane repolarization that in ventricular cells gives the typical spike-and-dome morphology of the APs. Membrane hyperpolarization is needed to close the $\mathrm{K}_{\mathrm{v}}$ channels for the following AP. Two current components have been described in human CMs that can be distinguished on the basis of rates of recovery from inactivation: the fast component $\left(I_{\mathrm{to}, \mathrm{f}}\right)$ with rates $<100 \mathrm{~ms}$ at $-80 \mathrm{mV}$ and the slow component $\left(I_{\text {to,s }}\right)$ that needs seconds to recover, and for this reason its functional effect on membrane repolarization is still quite unclear (Wettwer et al., 1994; Wang et al., 2003).

The $\mathrm{K}_{\mathrm{v}} 4.2$ and $\mathrm{K}_{\mathrm{v}} 4.3$ are the alpha subunits responsible for the $I_{\mathrm{to}, \mathrm{f}}$, while $I_{\mathrm{to}, \mathrm{s}}$ is generated by the $\mathrm{K}_{\mathrm{v}} 1.4$ subunit. Their expression in hiPSC-CMs was demonstrated after 27 days of differentiation and although there were no differences between $\mathrm{K}_{\mathrm{v}} 1.4$ and $\mathrm{K}_{\mathrm{v}} 4.3$ subunits, the levels of KChIP2 was very low especially when compared with human native cardiomyocytes (Cordeiro et al., 2013). Detailed studies of $I_{\text {to }}$ and its gating property on hiPSC-CMs were performed only by Cordeiro et al. (2013), even if $I_{\text {to }}$ presence was already reported in earlier studies (see Table 2) (Moretti et al., 2010; Ma et al., 2011).

It is interesting to note that, although patch-clamp analyses in single hiPSC-CMs revealed a robust $I_{\text {to }}$ in the vast majority of cells analyzed $(13.7 \pm 1.91 \mathrm{pA} / \mathrm{pF}$ at $+40 \mathrm{mV})$, comparable to that recorded in human neonatal atrial CMs (Wang et al., 2003), only $4 \%$ of the beating clusters and those with the most negative MDP $(-87.8 \pm 1.4 \mathrm{mV})$ exhibited APs with a 4-amino-pyridinesensitive spike and a dome morphology during phase 1 , suggesting the presence of $I_{\text {to }}$. This discrepancy has been explained by the fact that at a beating rate of $60-75 \mathrm{bpm}$ and at a depolarized
MDP, $I_{\text {to }}$ is largely inactivated due to its intrinsic slow recovery from inactivation.

These data highlight that the classification of hiPSC-CMs in atrial- ventricular- and sinoatrial-like, based on AP morphology/ APD ratio, does not correspond to a real commitment, but it is rather an artifact due to the immature and highly variable electrical properties of these cellular model and to the variable and depolarized MDP mainly caused by the lack of $I_{\mathrm{K} 1}$.

Variations of $I_{\mathrm{to}}$ current during maturation of hiPSC-CMs are not known. It can be assumed that decreasing the MDP, the contribution of $I_{\text {to }}$ in the first phase of repolarization will be emphasized.

$I_{\text {to,f }}$ was only recorded in hESC-CMs after 12 days in culture post-differentiation (Sartiani et al., 2007) and increases further on, but the current density recorded from hESC-CMs at 28 days (HES2cell line) was $\sim 3 \mathrm{pA} / \mathrm{pF}$ at $+60 \mathrm{mV}$ (Fu et al., 2011) which is much lower than $I_{\text {to }}$ densities in human atria from adult hearts $(\sim 14 \mathrm{pA} / \mathrm{pF},+60 \mathrm{mV})$ and infant hearts $(\sim 20 \mathrm{pA} / \mathrm{pF},+60 \mathrm{mV}$, 2.5-7 months old) (Wang et al. 2003).

\section{Slow Potassium Current $\left(I_{\mathrm{Ks}}\right)$}

$I_{\mathrm{Ks}}$ is the slow component of the delayed rectifier potassium current, that occurs during the repolarizing phase of the action potential. Its definition is linked to a slow activation and relatively slow deactivation of outward $\mathrm{K}^{+}$current that does not inactivate (Sanguinetti and Jurkiewicz, 1992; Wang et al., 1994). $I_{\mathrm{Ks}}$ can be distinguished from $I_{\mathrm{Kr}}$ as the Chromanol-293B sensitive component of the total outward current. Moreover, $I_{\mathrm{Ks}}$ is regulated by the sympathetic nervous system by means of $\beta$-adrenergic receptor and PKA signaling (Osteen et al., 2010); therefore, it abbreviates AP duration as a consequence of its slow deactivation which causes $I_{\mathrm{Ks}}$ to remain partially activated throughout the cardiac cycle.

KCNQ1 gene encoded for Kv7.1 $\alpha$ subunit that forms the homo-tetrameric channels responsible of $I_{\mathrm{Ks}}$, usually combined in heart with the auxiliary $\beta$-subunit KCNE1 (Furukawa et al., 2001). KCNQ1 expression in hiPSC-CMs was reported only after day 28 in several studies that model long-QT syndromes (LQT1 and LQT5) associated with KCNQ1 or KCNE1 mutations. $I_{\mathrm{Ks}}$ density varies between 0.31 and $2.9 \mathrm{pA} / \mathrm{pF}$ as reported in Table 2 . Few studies analyzed the presence of $I_{\mathrm{Ks}}$ in hiPSC-CMs. In one of these, it was found in $30 \%$ of the cells with a density of $0.31 \mathrm{pA} /$ $\mathrm{pF}$ (Ma et al., 2011), similar to that reported in native human ventricular CMs (0.18 pA/pF) (Virág et al., 2001). Other two studies instead (Moretti et al., 2010; Lee et al., 2016) described $I_{\mathrm{Ks}}$ in all cells and with a very high current density (2.5 and $2.9 \mathrm{pA} / \mathrm{pF}$, respectively). This $I_{\mathrm{Ks}}$ variability can be partly explained by a different expression of the accessory subunit KCNE1, a behavior already described in hESC-CMs by Wang and colleagues (2011).

\section{Rapid Delayed Rectifier Potassium Current $\left(I_{\mathrm{Kr}}\right)$}

$I_{\mathrm{Kr}}$ is the rapid component of the delayed rectifier potassium current formed by $\mathrm{K}_{\mathrm{v}} 11.1$ channel (human Ether-à-go-go-Related Gene, hERG, or KCNH2). Two splicing variants of KCNH2 (hERG $1 \mathrm{a}$ and $1 \mathrm{~b}$ ) are expressed in the cardiac tissue, complexed with MinK-related peptide 1 (MiRP1, encoded by KCNE2 gene). $I_{\mathrm{Kr}}$ contributes to the phase 3 repolarization phase 3 . 
$I_{\mathrm{Kr}}$ current is by far the most studied current in hiPSC-CMs mainly because these cell have been used in several studies to model long-QT syndromes linked to KCNH2 or MiRP1 mutations (Moretti et al., 2010; Itzhaki et al., 2011; Lahti et al. 2012; Bellin et al., 2013; Mehta et al., 2014).

Maximal $I_{\mathrm{Kr}}$ current density, measured as the E-4031-sensitive current, varies between 0.55 and $2.5 \mathrm{pA} / \mathrm{pF}$ as reported in Table 2. These values are in agreement with those reported in hESCCMs, but higher than those described in adult CMs, where $I_{\mathrm{Kr}}$ densities range between $0.25 \mathrm{pA} / \mathrm{pF}$ for ventricular CMs and $0.6 \mathrm{pA} /$ pF for atrial CMs (Magyar et al., 2000; Jost et al., 2009).

Doss and colleagues (2012) demonstrated the important role of $I_{\mathrm{Kr}}$ in the repolarization phase and in MDP determination in hiPSC-CMs, due to slow activation and deactivation kinetic of $I_{\mathrm{Kr}}$, but mainly because of the absence of $I_{\mathrm{K} 1}$ (Doss et al., 2012).

Jones and collaborators (2014) revealed a critical role for the hERG $1 \mathrm{~b}$ subunit in hiPSC-CM $I_{\mathrm{Kr}}$-mediated repolarization. By silencing this subunit with a specific shRNA, therefore forcing the homo-dimerization of hERG 1a, they obtained a proarrhythmic behavior in hiPSC-CMs: prolonged APD, early-after depolarizations and APD variability.

The same phenotype has been described when $I_{\mathrm{Kr}}$ was blocked by E-4031, dofetilide, or nefazodone (Lee et al., 2016) or in longQT patients-derived CMs carrying KCNH2 mutations (Ma et al., 2011; Itzhaki et al., 2011; Bellin et al., 2013; Mehta et al., 2014).

Time-dependent changes in $I_{\mathrm{Kr}}$ have been established in KhES1 cells, in which $I_{\mathrm{Kr}}$ density increased from $\sim 0.005 \mathrm{pA} / \mathrm{pF}$ to $\sim$ $0.30 \mathrm{pA} / \mathrm{pF}$ (measured at $0 \mathrm{mV}$ ) (Otsuji et al., 2010). Promoting hESC-CMs maturation with the biowire technique or with microRNA-1 transfection led to elevated $I_{\mathrm{Kr}}$ densities (Fu et al., 2011; Nunes et al., 2013).

\section{Inward Rectifier Potassium Current $\left(I_{\mathrm{K} 1}\right)$}

The inward rectifier potassium current $\left(I_{\mathrm{K} 1}\right)$ helps to stabilize the resting membrane potential of adult atrial and ventricular cardiomyocytes and contributes to the last phase of repolarization. The channels responsible for $I_{\mathrm{K} 1}$ are homo or hetero-oligomers formed by Kir2.1/2/3 proteins encoded by KCNJ1/KCNJ12/KCNJ4 genes, respectively.

The expression analyses of these Kir2.x isoforms in hiPSC-CMs at 160 days post differentiation revealed few (11\%) Kir2.1/Troponin $\mathrm{T}$ positive cells (Doss et al., 2012). It is indeed a common observation that hiPSC-CMs present a very small or negligible $I_{\mathrm{K} 1}$, even at late stages of differentiation, which explains the depolarized MDP and the autorhythmic phenotype of these cells. In particular, Doss and colleagues (2012) reported $-2.17 \pm 0.42$ $\mathrm{pA} / \mathrm{pF} \mathrm{Ba}^{2+}$-sensitive $I_{\mathrm{K} 1}$ current, considering cells between 18 and 121 days. However, more than 53\% of the cells analyzed showed very low or negligible $I_{\mathrm{K} 1}$ at $-100 \mathrm{mV}$ with the highest values recorded in late-stage hiPSC-CMs $(-3.49 \pm 0.91 \mathrm{pA} / \mathrm{pF}$ and $-2.17 \pm 0.72 \mathrm{pA} / \mathrm{pF}$ at 89 and 121 days post-differentiation, respectively).

More recently, Lee and colleagues (2016) recorded in 28-dayold hiPSC-CMs an $I_{\mathrm{K} 1}$ current density of $-5.1 \mathrm{pA} / \mathrm{pF}$, which is, however, still lower than the $-10 \mathrm{pA} / \mathrm{pF}$ reported in native ventricular CMs (Magyar et al., 2000). Nevertheless, several attempts have been carried out to mature hiPSC-CMs through an increase of $I_{\mathrm{K} 1}$. The approach adopted by Bett and colleagues (2013) and Meijer van Putten and colleagues (2015) consisted in artificially restore the missing $I_{\mathrm{K} 1}$ current through electronic expression, using the dynamic clamp. Recently, Vaidyanathan and colleagues (2016) increased the expression of Kir2.1 in hiPSC-CMs through lentiviral infection, leading to a maturation of the electrophysiological properties. Collectively, these results highlight that hiPSCCMs present electrical properties different from adult human CMs and some of these differences may be ascribed to the lack of $I_{\mathrm{K} 1}$ that can thus be seen as a maturation marker.

\section{NCX Current $\left(I_{N C X}\right)$}

The cellular plasma membrane contains several types of channels that mediate $\mathrm{Ca}^{2+}$ entry and two systems for $\mathrm{Ca}^{2+}$ extrusion: the sarcoendoplasmic reticulum $\mathrm{Ca}^{2+}$ ATPase (SERCA) and the $\mathrm{Na}^{+} /$ $\mathrm{Ca}^{2+}$ exchanger (NCX) (Blaustein and Lederer, 1999).

NCX exists in three isoforms, NCX-1, -2 , and -3 , but NCX1, encoded by solute carrier family 8 member A1 (SLC8A1) gene (Lytton, 2007), is the only isoform present in the heart (Quednau et al., 1997).

To allow cardiomyocyte relaxation, cytosolic $\mathrm{Ca}^{2+}$ concentration must be lowered. Thus, in the systolic contraction phase, NCX extrudes $\mathrm{Ca}^{2+}$ from the cytosol into the extracellular space (Blaustein and Lederer, 1999). The operation of NCX is fully reversible, and the direction of the movement of the transported ions depends entirely on the electrochemical gradients of $\mathrm{Na}^{+}$ and $\mathrm{Ca}^{2+}$ and on the number of ions that bind to the molecule and are transported. Under resting condition, the NCX acts to extrude $\mathrm{Ca}^{2+}$ from the cytoplasm (Brini and Carafoli, 2011). Therefore, NCX generates an inwardly directed membrane current $\left(I_{\mathrm{NCX}}\right)$ during sarcoplasmic reticulum $\mathrm{Ca}^{2+}$ release that contribute to maintain the plateau of the cardiac action potential (Aronsen et al., 2013). Indeed, computer modelling revealed that increased $\mathrm{I}_{\mathrm{NCX}}$ activity significantly delays repolarization of the cardiac AP (Pott et al., 2011).

NCX uses the energy stored in the electrochemical gradient of $\mathrm{Na}^{+}$in exchange for the countertransport of $\mathrm{Ca}^{2+}$ and during each cycle three $\mathrm{Na}^{+}$ions enter the cell and one $\mathrm{Ca}^{2+}$ ion is extruded, thus indicating an electrogenic transport (Blaustein and Lederer, 1999).

It has been shown that hESC-derived CMs express NCX1, although at lower levels and with a different profile, compared with porcine heart (Dolnikov et al., 2006). In these type of cells, NCX1 increased during cardiac differentiation and NCX current density was determined using the whole-cell patch-clamp technique (Fu et al., 2010). $I_{\mathrm{NCX}}$, defined as $\mathrm{Ni}^{2+}$-sensitive current, was functionally and robustly expressed in 47- and 97-day-old ventricular-like hESC-CMs. A voltage ramp from +60 to -120 $\mathrm{mV}$ elicited an almost linear current-voltage relationship of $I_{\mathrm{NCX}}$, similar to that previously described for fetal and adult mouse CMs (Reppel et al., 2007). The $I_{\mathrm{NCX}}$ densities in 40-day ventricular-like hESC-CMs were $-1.2 \pm 0.6 \mathrm{pA} / \mathrm{pF}(n=4)$ at $-120 \mathrm{mV}$ $\left(\mathrm{Ca}^{2+}\right.$ outward mode) and $3.6 \pm 1.0 \mathrm{pA} / \mathrm{pF}$ at $60 \mathrm{mV}\left(\mathrm{Ca}^{2+}\right.$ inward mode). Significant increase of $I_{\mathrm{NCX}}$, particularly in the $\mathrm{Ca}^{2+}$ outward mode, was observed in 97-day ventricular hESC-CMs $(-6.9 \pm 1.3 \mathrm{pA} / \mathrm{pF}$ or $\sim$ six-fold increase at $-120 \mathrm{mV} n=5$ and $7.9 \pm 1.3 \mathrm{pA} / \mathrm{pF}$ or $\sim$ two-fold at $60 \mathrm{mV}$ ) (Fu et al., 2010). Commercial iCell cardiomyocytes (Cellular Dynamics International), containing large and small myocytes derived from hiPSC were also evaluated (Fine et al., 2013). For the "larger" myocytes, the peak of $I_{\mathrm{NCX}}$ was $4.5 \pm 0.5 \mathrm{pA} / \mathrm{pF}$, equivalent to those of adult guinea pig or rabbit cardiomyocytes (Fine et al., 2013). 
Hwang and collaborators studied $\mathrm{Ca}^{2+}$ handling and cytosolic $\mathrm{Ca}^{2+}$ buffering properties of hiPSC-CMs generated from multiple hiPSC lines and the results were compared with isolated adult rabbit and mouse ventricular CMs (Hwang et al., 2015). Although hiPSC-CM cell volume was significantly smaller, cell capacitance to cell volume ratio and cytoplasmic $\mathrm{Ca}^{2+}$ buffering were not different from rabbit-CMs. hiPSC-CMs exhibited robust L-type $\mathrm{Ca}^{2+}$ currents, twitch $\mathrm{Ca}^{2+}$ transients and caffeine-releasable SR $\mathrm{Ca}^{2+}$ stores comparable to adult CMs. $\mathrm{Ca}^{2+}$ transport by SR Ca ATPase and NCX was similar in all hiPSC-CM lines, but slower compared with rabbit-CMs, although the relative contribution of the two systems was comparable to rabbit-CMs (Hwang et al., 2015).

\section{Conclusions and Future Outlooks}

The great excitement raised by the discovery of the reprogramming process, followed by the possibility to obtain virtually any kind of human cell, has turned, in these 10 years, into the awareness that our knowledge about the process of cell differentiation is extremely poor, especially when cells are newly generated from iPSCs. Nevertheless, several major limitations have been overcome: from developmental biology studies, several bioactive molecules have been identified and used to direct iPSC differentiation toward specific phenotypes. Indeed, today we can easily produce large numbers of almost pure human cardiomyocytes but still, we cannot use them as therapeutic agents. The major limitation lies in the immaturity of these cells artificially created in the lab; indeed to exploit their therapeutic potential, we need to learn how to promote their maturation.

Relevant to this point, a special mention must be addressed to the joining efforts of cell biologists and engineers in identifying and building systems that might accelerate the in vitro maturation of these cells (see Yang et al., 2014b). We must identify the developmental cellular stage we are dealing with, and to do so we need to find specific and selective functional markers. The study of the electrophysiology of the iPSC-derived cardiomyocytes can greatly help us in this process because it allows us to monitor very tiny changes in the cellular profile that could probably correspond to small steps toward maturity. Nevertheless, a certain degree of standardization among the different protocols is needed to highlight real biological differences among iPSC-CMs. In any case, despite the great limits that we have yet to overcome, patient-derived iPSC-CMs, at variance with ESC-CMs, give us the opportunity to model in vitro several human cardiac diseases, in order to identify the molecular mechanisms underlying the specific pathology, as well as to discover new therapeutic drugs.

\section{Acknowledgments}

A.B. and P.D.E. were funded by grants from Fondazione Cariplo.

\section{References}

Aronsen JM, Swift F, Sejersted OM. 2013. Cardiac sodium transport and excitation-contraction coupling. J Mol Cell Cardiol 61: 11-19.

Baruscotti M, DiFrancesco D, Robinson RB. 2000. Na(+) current contribution to the diastolic depolarization in newborn rabbit SA node cells. Am J Physiol Heart Circ Physiol 279:H2303-H2309.

Baruscotti M, Barbuti A, Bucchi A. 2010. The cardiac pacemaker current. J Mol Cell Cardiol 48:55-64.

Bellin M, Casini S, Davis RP, D'Aniello C, Haas J, Ward-van Oostwaard D, Tertoolen LG, Jung CB, Elliott DA, Welling A, Laugwitz KL, Moretti A, Mummery CL. 2013. Isogenic human pluripotent stem cell pairs reveal the role of a $\mathrm{KCNH} 2$ mutation in long-QT syndrome. EMBO J 32:3161-3175.

Bers DM. 2000. Calcium fluxes involved in control of cardiac myocyte contraction. Circ Res 87:275-281.

Bett GC, Kaplan AD, Lis A, Cimato TR, Tzanakakis ES, Zhou Q, Morales MJ, Rasmusson RL. 2013. Electronic "expression" of the inward rectifier in cardiocytes derived from human-induced pluripotent stem cells. Heart Rhythm 10:1903-1910.

Blaustein MP, Lederer WJ. 1999. Sodium/calcium exchange: its physiological implications. Physiol Rev 79:763-854.

Brade T, Pane LS, Moretti A, Chien KR, Laugwitz KL. 2013. Embryonic heart progenitors and cardiogenesis. Cold Spring Harb Perspect Med 3:a013847.

Brini M, Carafoli E. 2011. The plasma membrane $\mathrm{Ca}^{2}+$ ATPase and the plasma membrane sodium calcium exchanger cooperate in the regulation of cell calcium. Cold Spring Harb Perspect Biol 3:pii: a004168.

Burridge PW, Anderson D, Priddle H, Barbadillo Muñoz MD, Chamberlain S, Allegrucci C, Young LE, Denning C. 2007. Improved human embryonic stem cell embryoid body homogeneity and cardiomyocyte differentiation from a novel V-96 plate aggregation system highlights interline variability. Stem Cells 25 : 929-938.

Burridge PW, Matsa E, Shukla P, Lin ZC, Churko JM, Ebert AD, Lan F, Diecke S, Huber B, Mordwinkin NM, Plews JR, Abilez OJ, Cui B, Gold JD, Wu JC. 2014. Chemically defined generation of human cardiomyocytes. Nat Methods 11:855-860.

Cai B, Mu X, Gong D, Jiang S, Li J, Meng Q, Bai Y, Liu Y, Wang X, Tan X, Yang B, Lu Y. 2011. Difference of sodium currents between pediatric and adult human atrial myocytes: evidence for developmental changes of sodium channels. Int J Biol Sci 7: 708-714.

Catterall WA. 2000. Structure and regulation of voltage-gated $\mathrm{Ca}^{2+}$ channels. Annu Rev Cell Dev Biol 16:521-555.

Catterall WA. 2012. Voltage-gated sodium channels at 60: structure, function and pathophysiology. J Physiol 590:2577-2589.

Cordeiro JM, Nesterenko VV, Sicouri S, Goodrow RJ Jr, Treat JA, Desai M, Wu Y, Doss MX, Antzelevitch C, Di Diego JM. 2013. Identification and characterization of a transient outward $\mathrm{K}+$ current in human induced pluripotent stem cell-derived cardiomyocytes. J Mol Cell Cardiol 60:36-46.

Davies MP, An RH, Doevendans P, Kubalak S, Chien KR, Kass RS. 1996. Developmental changes in ionic channel activity in the embryonic murine heart. Circ Res 78:15-25.

Dell'Era P, Benzoni P, Crescini E, Valle M, Xia E, Consiglio A, Memo M. 2015. Cardiac disease modeling using induced pluripotent stem cell-derived human cardiomyocytes. World J Stem Cells 7:329-342.

Desbaillets I, Ziegler U, Groscurth P, Gassmann M. 2000. Embryoid bodies: an in vitro model of mouse embryogenesis. Exp Physiol 85:645-651.

Dolnikov K, Shilkrut M, Zeevi-Levin N, Gerecht-Nir S, Amit M, Danon A, Itskovitz-Eldor J, Binah O. 2006. Functional properties of human embryonic stem cell-derived cardiomyocytes: intracellular $\mathrm{Ca} 2$ + handling and the role of sarcoplasmic reticulum in the contraction. Stem Cells 24:236-245.

Doss MX, Di Diego JM, Goodrow RJ, Wu Y, Cordeiro JM, Nesterenko VV, Barajas-Martínez H, Hu D, Urrutia J, Desai M, Treat JA, Sachinidis A, Antzelevitch C. 2012. Maximum diastolic potential of human induced pluripotent stem cell-derived cardiomyocytes depends critically on I(Kr). PLoS One 7:e40288.

Fatima A, Xu G, Shao K, Papadopoulos S, Lehmann M, Arnáiz-Cot JJ, Rosa AO, Nguemo F, Matzkies M, Dittmann S, Stone SL, Linke $M$, Zechner $U$, Beyer V, Hennies HC, Rosenkranz $S$, Klauke B, Parwani AS, Haverkamp W, Pfitzer G, Farr M, Cleemann L, Morad M, Milting H, Hescheler J, Saric T. 2011. In vitro modeling of ryanodine receptor 2 dysfunction using human induced pluripotent stem cells. Cell Physiol Biochem 28:579592.

Fine M, Lu FM, Lin MJ, Moe O, Wang HR, Hilgemann DW. 2013. Human-induced pluripotent stem cell-derived cardiomyocytes for studies of cardiac ion transporters. Am J Physiol Cell Physiol 305:C481-C491. 
Fu JD, Jiang P, Rushing S, Liu J, Chiamvimonvat N, Li RA. 2010. $\mathrm{Na}^{+} / \mathrm{Ca}^{2+}$ exchanger is a determinant of excitation-contraction coupling in human embryonic stem cell-derived ventricular cardiomyocytes. Stem Cells Dev 19:773-782.

Fu JD, Rushing SN, Lieu DK, Chan CW, Kong CW, Geng L, Wilson KD, Chiamvimonvat N, Boheler KR, Wu JC, Keller G, Hajjar RJ, Li RA. 2011. Distinct roles of microRNA-1 and -499 in ventricular specification and functional maturation of human embryonic stem cell-derived cardiomyocytes. PLoS One 6:e27417.

Fujii S, Ayer RK Jr, DeHaan RL. 1988. Development of the fast sodium current in early embryonic chick heart cells. J Membr Biol 101:209-223.

Furukawa T, Koumi S, Sakakibara Y, Singer DH, Jia H, Arentzen CE, Backer CL, Wasserstrom JA. 1995. An analysis of lidocaine block of sodium current in isolated human atrial and ventricular myocytes. J Mol Cell Cardiol 27:831-846.

Furukawa $\mathrm{T}$, Ono $\mathrm{Y}$, Tsuchiya $\mathrm{H}$, Katayama $\mathrm{Y}$, Bang ML, Labeit $\mathrm{D}$, Labeit S, Inagaki N, Gregorio CC. 2001. Specific interaction of the potassium channel beta-subunit minK with the sarcomeric protein T-cap suggests a T-tubule-myofibril linking system. J Mol Biol 313:775-784.

Gaspar JA, Doss MX, Hengstler JG, Cadenas C, Hescheler J, Sachinidis A. 2014. Unique metabolic features of stem cells, cardiomyocytes, and their progenitors. Circ Res 114:1346-1360.

Gibson JK, Yue Y, Bronson J, Palmer C, Numann R. 2014. Human stem cell-derived cardiomyocytes detect drug-mediated changes in action potentials and ion currents. J Pharmacol Toxicol Methods 70:255-267.

Gonzalez R, Lee JW, Schultz PG. 2011. Stepwise chemically induced cardiomyocyte specification of human embryonic stem cells. Angew Chem Int Ed Engl 50:11181-11185.

Harrell MD, Harbi S, Hoffman JF, Zavadil J, Coetzee WA. 2007. Large-scale analysis of ion channel gene expression in the mouse heart during perinatal development. Physiol Genomics 28:273-283.

Hernández D, Millard R, Sivakumaran P, Wong RC, Crombie DE, Hewitt AW, Liang H, Hung SS, Pébay A, Shepherd RK, Dusting GJ, Lim SY. 2016. Electrical Stimulation Promotes Cardiac Differentiation of Human Induced Pluripotent Stem Cells. Stem Cells Int 2016:1718041.

Huttenbach Y, Ostrowski ML, Thaller D, Kim HS. 2001. Cell proliferation in the growing human heart: MIB-1 immunostaining in preterm and term infants at autopsy. Cardiovasc Pathol 10:119-123.

Hwang HS, Kryshtal DO, Feaster TK, Sánchez-Freire V, Zhang J, Kamp TJ, Hong CC, Wu JC, Knollmann BC. 2015. Comparable calcium handling of human iPSC-derived cardiomyocytes generated by multiple laboratories. J Mol Cell Cardiol 85:79-88.

Itzhaki I, Maizels L, Huber I, Zwi-Dantsis L, Caspi O, Winterstern A Feldman O, Gepstein A, Arbel G, Hammerman H, Boulos M, Gepstein L. 2011. Modelling the long QT syndrome with induced pluripotent stem cells. Nature 471:225-229.

Ivashchenko CY, Pipes GC, Lozinskaya IM, Lin Z, Xiaoping X, Needle S, Grygielko ET, Hu E, Toomey JR, Lepore JJ, Willette RN. 2013. Human-induced pluripotent stem cell-derived cardiomyocytes exhibit temporal changes in phenotype. Am J Physiol Heart Circ Physiol 305:H913-H922.

Jones DK, Liu F, Vaidyanathan R, Eckhardt LL, Trudeau MC, Robertson GA. 2014. hERG 1b is critical for human cardiac repolarization. Proc Natl Acad Sci U S A 111:18073-18077.

Jonsson MK, Vos MA, Mirams GR, Duker G, Sartipy P, de Boer TP van Veen TA. 2012. Application of human stem cell-derived cardiomyocytes in safety pharmacology requires caution beyond hERG. J Mol Cell Cardiol 52:998-1008.

Jost N, Acsai K, Horváth B, Bányász T, Baczkó I, Bitay M, Bogáts G, Nánási PP. 2009. Contribution of I Kr and I K1 to ventricular repolarization in canine and human myocytes: is there any influence of action potential duration? Basic Res Cardiol 104:33-41.

Jung $C B$, Moretti A, Mederos y Schnitzler M, lop L, Storch U, Bellin M, Dorn T, Ruppenthal S, Pfeiffer S, Goedel A, Dirschinger RJ, Seyfarth M, Lam JT, Sinnecker D, Gudermann T, Lipp P, Laugwitz KL. 2012. Dantrolene rescues arrhythmogenic RYR2 defect in a patient-specific stem cell model of catecholaminergic polymorphic ventricular tachycardia. EMBO Mol Med 4:180-191.
Kaese S, Verheule S. 2012. Cardiac electrophysiology in mice: a matter of size. Front Physiol 3:345.

Kamakura T, Makiyama T, Sasaki K, Yoshida Y, Wuriyanghai Y, Chen J, Hattori T, Ohno S, Kita T, Horie M, Yamanaka S, Kimura T. 2013. Ultrastructural maturation of human-induced pluripotent stem cell-derived cardiomyocytes in a long-term culture. Circ J 77:1307-1314.

Kaufmann SG, Westenbroek RE, Maass AH, Lange V, Renner A, Wischmeyer E, Bonz A, Muck J, Ertl G, Catterall WA, Scheuer T, Maier SK. 2013. Distribution and function of sodium channel subtypes in human atrial myocardium. J Mol Cell Cardiol 61: 133-141.

Kehat I, Kenyagin-Karsenti D, Snir M, Segev H, Amit M, Gepstein A, Livne E, Binah O, Itskovitz-Eldor J, Gepstein L. 2001. Human embryonic stem cells can differentiate into myocytes with structural and functional properties of cardiomyocytes. J Clin Invest 108:407-414.

Kodama I, Nikmaram MR, Boyett MR, Suzuki R, Honjo H, Owen JM. 1997. Regional differences in the role of the $\mathrm{Ca} 2+$ and $\mathrm{Na}+$ currents in pacemaker activity in the sinoatrial node. Am J Physiol 272(Pt 2):H2793-H2806.

Lahti AL, Kujala VJ, Chapman H, Koivisto AP, Pekkanen-Mattila M, Kerkelä E, Hyttinen J, Kontula K, Swan H, Conklin BR, Yamanaka S, Silvennoinen O, Aalto-Setälä K. 2012. Model for long QT syndrome type 2 using human iPS cells demonstrates arrhythmogenic characteristics in cell culture. Dis Model Mech 5: 220-230.

Lee S, Lee HA, Choi SW, Kim SJ, Kim KS. 2016. Evaluation of nefazodone-induced cardiotoxicity in human induced pluripotent stem cell-derived cardiomyocytes. Toxicol Appl Pharmacol 296: 42-53.

Li F, Wang X, Capasso JM, Gerdes AM. 1996. Rapid transition of cardiac myocytes from hyperplasia to hypertrophy during postnatal development. J Mol Cell Cardiol 28:1737-1746.

Li S, Chen G, Li RA. 2013. Calcium signalling of human pluripotent stem cell-derived cardiomyocytes. J Physiol 591:5279-5290.

Liang X, Wang G, Lin L, Lowe J, Zhang Q, Bu L, Chen Y, Chen J, Sun Y, Evans SM. 2013. HCN4 dynamically marks the first heart field and conduction system precursors. Circ Res 113:399-407.

Lieu DK, Liu J, Siu CW, McNerney GP, Tse HF, Abu-Khalil A, Huser T, Li RA. 2009. Absence of transverse tubules contributes to non-uniform $\mathrm{Ca}(2+)$ wavefronts in mouse and human embryonic stem cell-derived cardiomyocytes. Stem Cells Dev 18:14931500.

Lundy SD, Zhu WZ, Regnier M, Laflamme MA. 2013. Structural and functional maturation of cardiomyocytes derived from human pluripotent stem cells. Stem Cells Dev 22:1991-2002.

Lytton J. 2007. Na+/Ca2 + exchangers: three mammalian gene families control Ca2 + transport. Biochem J 406:365-382.

Ma J, Guo L, Fiene SJ, Anson BD, Thomson JA, Kamp TJ, Kolaja KL, Swanson BJ, January CT. 2011. High purity human-induced pluripotent stem cell-derived cardiomyocytes: electrophysiological properties of action potentials and ionic currents. Am J Physiol Heart Circ Physiol 301:H2006-H2017.

Ma D, Wei H, Zhao Y, Lu J, Li G, Sahib NB, Tan TH, Wong KY, Shim W, Wong P, Cook SA, Liew R. 2013. Modeling type 3 long QT syndrome with cardiomyocytes derived from patient-specific induced pluripotent stem cells. Int J Cardiol 168:5277-5286.

Ma D, Wei H, Lu J, Huang D, Liu Z, Loh LJ, Islam O, Liew R, Shim W, Cook SA. 2015. Characterization of a novel KCNQ1 mutation for type 1 long QT syndrome and assessment of the therapeutic potential of a novel IKs activator using patient-specific induced pluripotent stem cell-derived cardiomyocytes. Stem Cell Res Ther 6:39.

Magyar J, lost N, Körtvély A, Bányász T, Virág L, Szigligeti P, Varró A, Opincariu M, Szécsi J, Papp JG, Nánási PP. 2000. Effects of endothelin-1 on calcium and potassium currents in undiseased human ventricular myocytes. Pflugers Arch 441:144-149.

Malan D, Friedrichs S, Fleischmann BK, Sasse P. 2011. Cardiomyocytes obtained from induced pluripotent stem cells with long-QT syndrome 3 recapitulate typical disease-specific features in vitro. Circ Res 109:841-847.

Malan D, Zhang M, Stallmeyer B, Müller J, Fleischmann BK, Schulze-Bahr E, Sasse P, Greber B. 2016. Human iPS cell model 
of type 3 long QT syndrome recapitulates drug-based phenotype correction. Basic Res Cardiol 111:14.

Mangoni ME, Nargeot J. 2008. Genesis and regulation of the heart automaticity. Physiol Rev 88:919-982.

Mathur A, Ma Z, Loskill P, Jeeawoody S, Healy KE. 2016. In vitro cardiac tissue models: current status and future prospects. Adv Drug Deliv Rev 96:203-213.

McDonald TF, Sachs HG, DeHaan RL. 1973. Tetrodotoxin desensitization in aggregates of embryonic chick heart cells. J Gen Physiol 62:286-302.

Mehta A, Chung YY, Ng A, Iskandar F, Atan S, Wei H, Dusting G, Sun W, Wong P, Shim W. 2011. Pharmacological response of human cardiomyocytes derived from virus-free induced pluripotent stem cells. Cardiovasc Res 91:577-586.

Mehta A, Sequiera GL, Ramachandra CJ, Sudibyo Y, Chung Y, Sheng J, Wong KY, Tan TH, Wong P, Liew R, Shim W. 2014. Retrafficking of hERG reverses long QT syndrome 2 phenotype in human iPS-derived cardiomyocytes. Cardiovasc Res 102:497506.

Meijer van Putten RM, Mengarelli I, Guan K, Zegers JG, van Ginneken AC, Verkerk AO, Wilders R. 2015. Ion channelopathies in human induced pluripotent stem cell derived cardiomyocytes: a dynamic clamp study with virtual IK1. Front Physiol 6:7.

Milani-Nejad N, Janssen PM. 2014. Small and large animal models in cardiac contraction research: advantages and disadvantages. Pharmacol Ther 141:235-249.

Mozaffarian D, Benjamin EJ, Go AS, Arnett DK, Blaha MJ, Cushman $M$, de Ferranti S, Després JP, Fullerton HJ, Howard VJ, Huffman MD, Judd SE, Kissela BM, Lackland DT, Lichtman JH, Lisabeth LD, Liu S, Mackey RH, Matchar DB, McGuire DK, Mohler ER 3rd, Moy CS, Muntner P, Mussolino ME, Nasir K, Neumar RW, Nichol G, Palaniappan L, Pandey DK, Reeves MJ, Rodriguez CJ, Sorlie PD, Stein J, Towfighi A, Turan TN, Virani SS, Willey JZ, Woo D, Yeh RW, Turner MB; American Heart Association Statistics Committee and Stroke Statistics Subcommittee. 2015. Heart disease and stroke statistics--2015 update: a report from the American Heart Association. Circulation 131:e535.

Moretti A, Bellin M, Welling A, Jung CB, Lam JT, Bott-Flügel L, Dorn T, Goedel A, Höhnke C, Hofmann F, Seyfarth M, Sinnecker D, Schömig A, Laugwitz KL. 2010. Patient-specific induced pluripotent stem-cell models for long-QT syndrome. N Engl J Med 363:1397-1409.

Mummery C, Ward-van Oostwaard D, Doevendans P, Spijker R, van den Brink S, Hassink R, van der Heyden M, Opthof T, Pera M, de la Riviere AB, Passier R, Tertoolen L. 2003. Differentiation of human embryonic stem cells to cardiomyocytes: role of coculture with visceral endoderm-like cells. Circulation 107:2733-2740.

Nerbonne JM, Kass RS. 2005. Molecular physiology of cardiac repolarization. Physiol Rev 85:1205-1253.

Niwa N, Nerbonne JM. 2010. Molecular determinants of cardiac transient outward potassium current (I(to)) expression and regulation. J Mol Cell Cardiol 48:12-25.

Nunes SS, Miklas JW, Liu J, Aschar-Sobbi R, Xiao Y, Zhang B, Jiang J, Massé S, Gagliardi M, Hsieh A, Thavandiran N, Laflamme MA, Nanthakumar K, Gross GJ, Backx PH, Keller G, Radisic M. 2013. Biowire: a platform for maturation of human pluripotent stem cell-derived cardiomyocytes. Nat Methods 10: 781-787.

Ono K, lijima T. 2010. Cardiac T-type $\mathrm{Ca}(2+)$ channels in the heart. J Mol Cell Cardiol 48:65-70.

Osteen JD, Gonzalez C, Sampson KJ, Iyer V, Rebolledo S, Larsson HP, Kass RS. 2010. KCNE1 alters the voltage sensor movements necessary to open the KCNQ1 channel gate. Proc Natl Acad Sci U S A 107:22710-22715.

Otsuji TG, Minami I, Kurose Y, Yamauchi K, Tada M, Nakatsuji N. 2010. Progressive maturation in contracting cardiomyocytes derived from human embryonic stem cells: qualitative effects on electrophysiological responses to drugs. Stem Cell Res 4:201213.

Pelzmann B, Schaffer P, Bernhart E, Lang P, Mächler H, Rigler B, Koidl B. 1998. L-type calcium current in human ventricular myocytes at a physiological temperature from children with tetralogy of Fallot. Cardiovasc Res 38:424-432.
Perrin MJ, Adler A, Green S, Al-Zoughool F, Doroshenko P, Orr N, Uppal S, Healey JS, Birnie D, Sanatani S, Gardner M, Champagne J, Simpson C, Ahmad K, van den Berg MP, Chauhan V, Backx PH, van Tintelen JP, Krahn AD, Gollob MH. 2014. Evaluation of genes encoding for the transient outward current (Ito) identifies the KCND2 gene as a cause of J-wave syndrome associated with sudden cardiac death. Circ Cardiovasc Genet 7:782-789.

Poolman RA, Brooks G. 1998. Expressions and activities of cell cycle regulatory molecules during the transition from myocyte hyperplasia to hypertrophy. J Mol Cell Cardiol 30:2121-2135.

Pott C, Eckardt L, Goldhaber Jl. 2011. Triple threat: the $\mathrm{Na}+/$ $\mathrm{Ca} 2+$ exchanger in the pathophysiology of cardiac arrhythmia, ischemia and heart failure. Curr Drug Targets 12:737-747.

Quednau BD, Nicoll DA, Philipson KD. 1997. Tissue specificity and alternative splicing of the $\mathrm{Na}+/ \mathrm{Ca} 2+$ exchanger isoforms NCX1, NCX2, and NCX3 in rat. Am J Physiol 272:C1250-C1261.

Ren Y, Lee MY, Schliffke S, Paavola J, Amos PJ, Ge X, Ye M, Zhu S, Senyei G, Lum L, Ehrlich BE, Qyang Y. 2011. Small molecule Wnt inhibitors enhance the efficiency of BMP-4-directed cardiac differentiation of human pluripotent stem cells. J Mol Cell Cardiol 51:280-287.

Reppel M, Sasse P, Malan D, Nguemo F, Reuter H, Bloch W, Hescheler J, Fleischmann BK. 2007. Functional expression of the $\mathrm{Na}+/ \mathrm{Ca} 2+$ exchanger in the embryonic mouse heart. $\mathrm{J}$ Mol Cell Cardiol 42:121-132.

Ribeiro MC, Tertoolen LG, Guadix JA, Bellin M, Kosmidis G, D'Aniello C, Monshouwer-Kloots J, Goumans MJ, Wang YL, Feinberg AW, Mummery CL, Passier R. 2015. Functional maturation of human pluripotent stem cell derived cardiomyocytes in vitro--correlation between contraction force and electrophysiology. Biomaterials 51:138-150.

Sakakibara Y, Wasserstrom JA, Furukawa T, Jia H, Arentzen CE, Hartz RS, Singer DH. 1992. Characterization of the sodium current in single human atrial myocytes. Circ Res 71:535-546.

Sanguinetti MC, Jurkiewicz NK. 1992. Role of external Ca2 + and $\mathrm{K}+$ in gating of cardiac delayed rectifier $\mathrm{K}+$ currents. Pflugers Arch 420:180-186.

Sartiani L, Bettiol E, Stillitano F, Mugelli A, Cerbai E, Jaconi ME. 2007. Developmental changes in cardiomyocytes differentiated from human embryonic stem cells: a molecular and electrophysiological approach. Stem Cells 25:1136-1144.

Satin J, Kehat I, Caspi O, Huber I, Arbel G, Itzhaki I, Magyar J, Schroder EA, Perlman I, Gepstein L. 2004. Mechanism of spontaneous excitability in human embryonic stem cell derived cardiomyocytes. J Physiol 559(Pt 2):479-496.

Scavone A, Capilupo D, Mazzocchi N, Crespi A, Zoia S, Campostrini G, Bucchi A, Milanesi R, Baruscotti M, Benedetti S, Antonini S, Messina G, DiFrancesco D, Barbuti A. 2013. Embryonic stem cell-derived CD166 + precursors develop into fully functional sinoatrial-like cells. Circ Res 113:389-398.

Schram G, Pourrier M, Melnyk P, Nattel S. 2002. Differential distribution of cardiac ion channel expression as a basis for regional specialization in electrical function. Circ Res 90:939-950.

Sheng X, Reppel M, Nguemo F, Mohammad FI, Kuzmenkin A, Hescheler J, Pfannkuche K. 2012. Human pluripotent stem cellderived cardiomyocytes: response to TTX and lidocain reveals strong cell to cell variability. PLoS One 7:e45963.

Später D, Abramczuk MK, Buac K, Zangi L, Stachel MW, Clarke J, Sahara M, Ludwig A, Chien KR. 2013. A HCN4 + cardiomyogenic progenitor derived from the first heart field and human pluripotent stem cells. Nat Cell Biol 15:1098-1106.

Spencer Cl, Baba S, Nakamura K, Hua EA, Sears MA, Fu CC, Zhang J, Balijepalli S, Tomoda K, Hayashi Y, Lizarraga P, Wojciak J, Scheinman MM, Aalto-Setälä K, Makielski JC, January CT, Healy KE, Kamp TJ, Yamanaka S, Conklin BR. 2014. Calcium transients closely reflect prolonged action potentials in iPSC models of inherited cardiac arrhythmia. Stem Cell Reports 3: 269-281.

Stillitano F, Lonardo G, Giunti G, Del Lungo M, Coppini R, Spinelli V, Sartiani L, Poggesi C, Mugelli A, Cerbai E. 2013. Chronic atrial fibrillation alters the functional properties of If in the human atrium. J Cardiovasc Electrophysiol 24:1391-1400. 
Synnergren J, Améen C, Jansson A, Sartipy P. 2012. Global transcriptional profiling reveals similarities and differences between human stem cell-derived cardiomyocyte clusters and heart tissue. Physiol Genomics 44:245-258.

Takahashi K, Yamanaka S. 2006. Induction of pluripotent stem cells from mouse embryonic and adult fibroblast cultures by defined factors. Cell 126:663-676.

Takahashi K, Tanabe K, Ohnuki M, Narita M, Ichisaka T, Tomoda K, Yamanaka S. 2007. Induction of pluripotent stem cells from adult human fibroblasts by defined factors. Cell 131:861-872.

Tohyama S, Hattori F, Sano M, Hishiki T, Nagahata Y, Matsuura T, Hashimoto H, Suzuki T, Yamashita H, Satoh Y, Egashira T, Seki T, Muraoka N, Yamakawa H, Ohgino Y, Tanaka T, Yoichi M, Yuasa S, Murata M, Suematsu M, Fukuda K. 2013. Distinct metabolic flow enables large-scale purification of mouse and human pluripotent stem cell-derived cardiomyocytes. Cell Stem Cell 12: 127-137.

Tran TH, Wang X, Browne C, Zhang Y, Schinke M, Izumo S, Burcin M. 2009. Wnt3a-induced mesoderm formation and cardiomyogenesis in human embryonic stem cells. Stem Cells 27:18691878.

Uosaki H, Fukushima H, Takeuchi A, Matsuoka S, Nakatsuji N, Yamanaka S, Yamashita JK. 2011. Efficient and scalable purification of cardiomyocytes from human embryonic and induced pluripotent stem cells by VCAM1 surface expression. PLoS One 6: e23657.

Vaidyanathan R, Markandeya YS, Kamp TJ, Makielski JC, Janaury CT, Eckhardt LL. 2016. IK1-enhanced human induced pluripotent stem cell-derived cardiomyocytes: an improved cardiomyocyte model to investigate inherited arrhythmia syndromes. Am J Physiol Heart Circ Physiol 310:H1611-H1621.

van den Berg CW, Okawa S, Chuva de Sousa Lopes SM, van Iperen L, Passier R, Braam SR, Tertoolen LG, del Sol A, Davis RP, Mummery CL. 2015. Transcriptome of human foetal heart compared with cardiomyocytes from pluripotent stem cells. Development 142:3231-3238.

van den Heuvel NH, van Veen TA, Lim B, Jonsson MK. 2014. Lessons from the heart: mirroring electrophysiological characteristics during cardiac development to in vitro differentiation of stem cell derived cardiomyocytes. J Mol Cell Cardiol 67:12-25.

Virág L, lost N, Opincariu M, Szolnoky J, Szécsi J, Bogáts G, Szenohradszky P, Varró A, Papp JG. 2001. The slow component of the delayed rectifier potassium current in undiseased human ventricular myocytes. Cardiovasc Res 49:790-797.

Wang Z, Fermini B, Nattel S. 1994. Rapid and slow components of delayed rectifier current in human atrial myocytes. Cardiovasc Res 28:1540-1546.
Wang Y, Xu H, Kumar R, Tipparaju SM, Wagner MB, Joyner RW. 2003. Differences in transient outward current properties between neonatal and adult human atrial myocytes. J Mol Cell Cardiol 35:1083-1092.

Wang K, Terrenoire C, Sampson KJ, lyer V, Osteen JD, Lu J, Keller G, Kotton DN, Kass RS. 2011. Biophysical properties of slow potassium channels in human embryonic stem cell derived cardiomyocytes implicate subunit stoichiometry. J Physiol 589(Pt 24): 6093-6104.

Weisbrod D, Peretz A, Ziskind A, Menaker N, Oz S, Barad L, Eliyahu S, Itskovitz-Eldor J, Dascal N, Khananshvili D, Binah O, Attali B. 2013. SK4 Ca2 + activated K + channel is a critical player in cardiac pacemaker derived from human embryonic stem cells. Proc Natl Acad Sci U S A 110:E1685-E1694.

Wettwer E, Amos GJ, Posival H, Ravens U. 1994. Transient outward current in human ventricular myocytes of subepicardial and subendocardial origin. Circ Res 75:473-482.

Yang L, Soonpaa MH, Adler ED, Roepke TK, Kattman SJ, Kennedy M, Henckaerts E, Bonham K, Abbott GW, Linden RM, Field LJ, Keller GM. 2008. Human cardiovascular progenitor cells develop from a KDR + embryonic-stem-cell-derived population. Nature 453:524-528.

Yang X, Rodriguez M, Pabon L, Fischer KA, Reinecke H, Regnier M, Sniadecki NJ, Ruohola-Baker H, Murry CE. 2014a. Tri-iodo-Ithyronine promotes the maturation of human cardiomyocytesderived from induced pluripotent stem cells. J Mol Cell Cardiol 72:296-304.

Yang X, Pabon L, Murry CE. 2014b. Engineering adolescence: maturation of human pluripotent stem cell-derived cardiomyocytes. Circ Res 114:511-523.

Yu L, Gao S, Nie L, Tang M, Huang W, Luo H, Hu X, Xi J, Zhu M, Zheng Y, Gao L, Zhang L, Song Y, Hescheler J, Liang H. 2011. Molecular and functional changes in voltage-gated $\mathrm{Na}$ ? channels in cardiomyocytes during mouse embryogenesis. Circ J 75: 2071-2079.

Zhang Z, He Y, Tuteja D, Xu D, Timofeyev V, Zhang Q, Glatter KA, Xu Y, Shin HS, Low R, Chiamvimonvat N. 2005. Functional roles of Cav1.3(alpha1D) calcium channels in atria: insights gained from gene-targeted null mutant mice. Circulation 112:1936-1944.

Zhang J, Wilson GF, Soerens AG, Koonce CH, Yu J, Palecek SP, Thomson JA, Kamp TJ. 2009. Functional cardiomyocytes derived from human induced pluripotent stem cells. Circ Res 104:e30-e41.

Zwi L, Caspi O, Arbel G, Huber I, Gepstein A, Park IH, Gepstein L. 2009. Cardiomyocyte differentiation of human induced pluripotent stem cells. Circulation 120:1513-1523. 